\title{
Identification of Global Indicators for Regulatory Risk Management in Production Platforms - Case Study of Brazilian Industry
}

\author{
Alex Garcia de Almeida \\ Technical Advisor at Safety and Environmental Department, National Agency of Petroleum, Natural Gas and Biofuels \\ Av Rio Branco 65, 18 andar, Centro, Rio de Janeiro-RJ, Brazil \\ E-mail: agalmeida@anp.gov.br \\ Marco Antonio Gaya de Figueiredo \\ Operation a Industrial Project Department, State University of Rio de Janeiro \\ São Francisco Xavier Street , 524, Maracanã - Rio de Janeiro Cep 20550-900, Brazil \\ E-mail:mgaya@uerj.br \\ Received 20 April 2014 \\ Accepted 1 August 2014
}

\begin{abstract}
This study aims to analyze different indicator's programs from regulators and other organizations, select and apply methods to normalize and compose global indicator. Using obtained information related to risk management system and incidents from 67 oil and gas production platforms in Brazil, the results show a new method to follow offshore performance and its companies, in lagging and leading focuses, showing a tool to improve Regulator's overview.
\end{abstract}

Keywords: offshore platforms, process safety, leading indicator, lagging indicator, global indicator

\section{Introduction}

The selection and monitoring of performance indicators, both in a leading focus to monitor the performance of safety barriers, as in lagging focus to monitor precursors events of major accidents, are the best tools to provide information about how a risk management process is conduced [4][5][6]. It can indicate if corrective actions are needed to achieve management goals at various levels, and, in the end, monitor the risk of major accidents. [7].

The experience of industry shows that without an effective regulatory oversight at oil and gas industrial activities, the risk of accidents will not be reduced, nor will industry prepare effectively to respond to major emergencies [8]. To be sure that all actions are going in a right direction, regulator's can use safety indicators to follow safety performance and show deviations and the need to add corrective actions. As examples of this approach, the project Trends in Risk Level (RNNP) [9] and the United Kingdom Health and Safety Executive (HSE) [10] are nowadays in use. In this context, it becomes reasonable that in the regulatory level that exist tools for monitoring the platform's performance and oil companies' risk management to have a correct approach to set rules to regulated activities. All of it in sense to achieve sustainable industry's growth ensuring a good level of safety in regulated activities and applying regulators efforts in a reasonable. 
The Brazilian regulator offshore authority ${ }^{1}$ released in 2007 a non prescriptive regulation based on a safety management system and has been implementing actions to increase industry's risk awareness and lead a safety continuous improvement environment of all offshore activities, as regular regulator's audits, accident investigations, reports, meetings and workshops. This regulatory risk control regulation based on a Process Safety Management System (PSMS) allows to achieve an indicators monitoring program for a new step on this development, giving information to improve the results evaluation of regulatory activities.

\section{Process Safety Management Systems}

The PSMS have a variety of meanings and purposes. The AIChE defines PSMS as a management system focused on prevention, preparedness, mitigation, response and recovery from catastrophic events associated with plant processes [3]. Also according to the AIChE, the PSMS is the discipline for managing the integrity of the operation of systems and processes that handle hazardous substances by applying good engineering practices, operation and maintenance [7]. It can be translated into the prevention and control of risks that have the potential for release of hazardous substances and energy. The organization of procedures, behaviors and actions to be taken and checked for systematic implementation of an effective process risk management is usually done by adoption of a management practices in a PSMS format ${ }^{2}$.

\subsection{Performance Indicators used in risk management}

The majority of indicators definitions tells that they are mainly used to information aquisition for management decision making related to a relevant issue [11]. For the word "performance", it is indicated that it contains the idea of something that has already been done, executed or performed [12]. Therefore, performance indicators have the function to transmit information about processes that occured in the past for adoption of actions to follow an objective.

Frequently, a retrospective analysis shows that early signs arising from safety indicators could avoid major

\footnotetext{
${ }^{1}$ Agência Nacional de Petróleo, gás natural e biocombustíveis (ANP)

${ }^{2}$ More information in SEPEDA, Adrian L.; Understanding Process Safety Management, CEP Magazine, Aug. 2010, AIChE, 2010
}

accidents if detected and managed timely [13]. Thus, safety performance indicators or just "safety indicators" are measures that seek to give information if a system is operating within chosen safety bounds to ensure that major accident risks are under control. Anyway, they intend to indicate that the preventive and mitigative safeguards and assumptions considered for risk acceptance process are applicable, reliable and active. In the other hand can denounce irrelevance, unreliability or inactivity for an early detection of a non tolerable risk to demand pro-active actions to its reduction.

\subsubsection{Leading indicators}

According to Hopkins [14], leading indicators are able to measure the ongoing risk management process and make predictions at sufficiently early stages to enable interruption of evolution course, reverse the process and avoid the fact. Another definition describes leading indicators as a type of accident precursors and reports that this kind of indicators are conditions, events and actions that precede an undesirable events and which have value in predict the proximity of an accident, near miss incident or undesirable safety condition. In this sense, leading indicators are related to proactive activities that identify and evaluate hazards, eliminate, control, or mitigate the risk [15].

HW Heinrich in 1931 introduced the widespread accident pyramid based on his experience with the insurance industry (Fig. 1). It has two basic concepts: one is that accidents can be placed on a scale representing the degree of impact and the other is that many precursors incidents occurs with minor

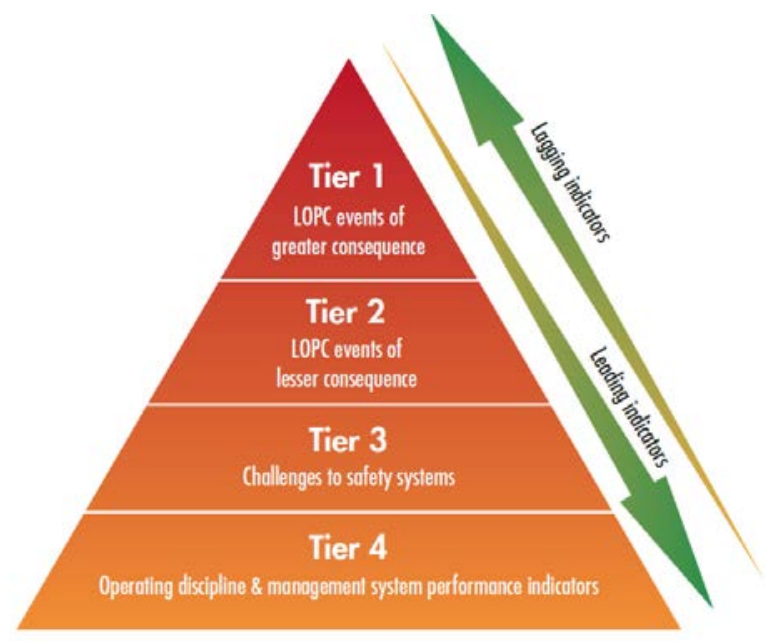

Fig. 1. Process Safety Indicator Pyramid [15]. 
consequences compared to accidents with large consequences. This representation establishes a predictive relationship between minor and major incidents [16]. Large explosions and other disasters are rare events and many companies did not record any event or only few were recorded in the last 50 years at the same industry (top of the pyramid of accidents). Thus, the number of occurrence of these events is not a good indicator of the probability of occurrence of major accidents [6].

\subsubsection{Lagging indicators}

The lagging indicators generally reflect past experience and are associated with undesirable events and adoption of corrective actions to avoid the recurrence of such events. These indicators are often not sufficient for a preventive program, because the accidental events that generate this type of measure indicators are rare and do not allow a statistical prediction [17]. Lagging indicators are generally viewed as direct measures of damages, however, may also be included incidents of unexpected losses of containment and failure on demand of safety critical systems. The fact is that not all damages and failures are recorded as lagging data, which complicates the design of a boundary between different types of indicators [18].

\subsection{Global indicators}

The search for global indicators has been currently quite intensified as a way to manage different activities using the lowest possible number of information, or an indicator that integrates different information, allowing a responsible decision making to manage applied resources. In the chemical and petrochemical industries, the implementation of global indicators is already an established fact [16].

A global indicator represents a way to specify the evaluation of organizational performance, based on indicators combined and grouped for a determined focus. Global indicators allow us to conclude about implementation effectiveness measurement of an aspect and can be a tool to correlate complex concepts and translate this in simple numerical information [19].

\section{Methodology}

\subsection{Identification of requirements to be considered in the formation of global safety indicators}

The platforms that are in operation in Brazil are required to comply with a safety regulation established by ANP Regulation 43/2007 [20] (also called SGSO). It demands the implementation of a set of good practices developed as a PSMS focused operational risk control. It relies on the adoption of seventeen management practices, showed in Table 1, that are interrelated and are incorporated into all phases of a project from its conception until its decommissioning [20].

Table 1. Management Practices (MP) required by SGSO [19].

\begin{tabular}{|l|l|}
\hline \multicolumn{1}{|c|}{ MP } & \multicolumn{1}{|c|}{ Description } \\
\hline MP 1 & $\begin{array}{l}\text { Safety Culture, Commitment and Responsibility } \\
\text { Management }\end{array}$ \\
\hline MP 2 & Personnel Involvement \\
\hline MP 3 & $\begin{array}{l}\text { Personal Qualification, Training and } \\
\text { Performance }\end{array}$ \\
\hline MP 4 & Working Environment and Human Factors \\
\hline MP 5 & $\begin{array}{l}\text { Selection, Management and Control of } \\
\text { Contractors }\end{array}$ \\
\hline MP 6 & $\begin{array}{l}\text { Monitoring and Continuous Improvement } \\
\text { Performance }\end{array}$ \\
\hline MP 7 & Audits \\
\hline MP 8 & Management of Information and Documentation \\
\hline MP 9 & Incident Investigation \\
\hline MP 10 & $\begin{array}{l}\text { Project, Construction, Installation } \\
\text { Deactivation }\end{array}$ \\
\hline MP 11 & Operational Safety Critical Elements \\
\hline MP 12 & Risk Identification and Analysis \\
\hline MP 13 & Asset Integrity \\
\hline MP 14 & Planning and Management Major Emergencies \\
\hline MP 15 & Operational Procedures \\
\hline MP 16 & Management of Change \\
\hline MP17 & $\begin{array}{l}\text { Work Safety Practices and Control Procedures } \\
\text { for Special Activities }\end{array}$ \\
\hline
\end{tabular}

\subsubsection{Identified leading indicators}

Checking guidelines and reports of safety indicators key programs already disclosed by regulatory authorities [21], it was observed that information taken from leading indicators contribute to act in a preventive way, to identify and correct non acceptable behaviors aiming to follow risk acceptance criteria in a regulatory point of 
view prior to the occurrence of major accidents [6]. As SGSO is a regulatory instrument of risk control and has a primarily preventive focus, leading indicators was settled based on information acquisition through specific parameters and sub groups as shown in Table 2.

Table 2. Subgroups and parameters to be monitored under leading focus.

\begin{tabular}{|c|l|}
\hline \multicolumn{2}{|c|}{ INDICATORS RELATED TO LEADING FOCUS } \\
\hline Subgroup & Parameters \\
\hline LEADERSHIP, & Involvement of Personnel \\
MANAGEMENT & Qualifications, training and personal \\
AND & performance \\
PERSONNEL & Monitoring and Continuous \\
& Performance improvement \\
& Audits \\
& Accident investigation \\
\hline SYSTEMS AND & Identification and Risk Analysis \\
TECHNOLOGY & Mechanical Integrity and Safety \\
& Critical Systems \\
& Planning and Management of Major \\
Emergencies \\
\hline OPERATIONAL & Change Management \\
PRACTICES & Safe work practices \\
\hline
\end{tabular}

Beaconed in leading focus established subgroups and considering identified parameters based on SGSO, indicators were identified for each subgroup.

\subsubsection{Identified lagging indicators}

Accidental events classified as catastrophic, involving the death of many people, severe environmental and other damage to businesses rarely occur, not allowing to perform a statistical analysis. However, prior to these disasters, less damage incidents (precursor events) occur and are good indicators for monitor and prevent major accidents. Thus, in this text, lagging indicators were grouped according to their kind and characteristics in order to support its proposition, from less to more severe events [22] [23]. The groups defined are shown in Table 3 and are divided into Operational Deviations; Loss of Primary Containment; Fires and Collisions.

Table 3. Parameters identified for indicators related to the acquisition of lagging focus.

\begin{tabular}{|l|l|}
\hline \multicolumn{2}{|c|}{ SUBGROUP RELATED TO LAGGING FOCUS } \\
\hline \multicolumn{1}{|c|}{ Subgroup } & Parameters \\
\hline $\begin{array}{l}\text { Operational } \\
\text { deviations }\end{array}$ & Emergency Shutdowns \\
\hline \multirow{2}{*}{$\begin{array}{c}\text { Loss of Primary } \\
\text { Contention }\end{array}$} & $\begin{array}{l}\text { Oil spills without fire } \\
\text { Oil spills with fire } \\
\text { Major spills } \\
\text { Significant spills }\end{array}$ \\
\hline
\end{tabular}

\begin{tabular}{|c|l|}
\hline & Major Natural Gas Leaks \\
& Significant Natural Gas Leaks \\
& $\mathrm{H}_{2} \mathrm{~S}$ release \\
\hline Fires & Major fire \\
& Significant fire \\
\hline Collisions & $\begin{array}{l}\text { Major collision } \\
\text { Significant collision }\end{array}$ \\
\hline
\end{tabular}

\subsection{The global indicator indicators related to leading and lagging focus}

The first step to create global indicators was the validation of chosen indicators by experts in the field of risk management in offshore activities. Each subgroup was evaluated by 9 skilled professionals, with plenty of knowledge in SGSO and risk management of offshore activities which evaluated the significance of the proposed indicators. This validation was made together to the prioritization evaluation, using criteria showed in tables 4 and 5 [24][25].

Table 4. Grades used in validation of the indicators.

\begin{tabular}{|l|l|l|}
\hline Criteria & Note & \multicolumn{1}{|c|}{ Justifications } \\
\hline Not relevant & $\begin{array}{l}1,0 \\
-\end{array}$ & $\begin{array}{l}\text { The proposed indicator has no } \\
\text { relevance in the composition of a } \\
\text { global indicator. }\end{array}$ \\
\hline $\begin{array}{l}\text { Low } \\
\text { relevance }\end{array}$ & $\begin{array}{l}2,6 \\
-\end{array}$ & $\begin{array}{l}\text { The proposed indicator has low } \\
\text { relevance in the composition of a } \\
\text { global indicator even though } \\
\text { related to risk area }\end{array}$ \\
\hline $\begin{array}{l}\text { Average } \\
\text { relevance }\end{array}$ & $\begin{array}{l}5,1 \\
-\end{array}$ & $\begin{array}{l}\text { The proposed indicator is } \\
\text { important in composing a global } \\
\text { indicator related risk area }\end{array}$ \\
\hline $\begin{array}{l}\text { High } \\
\text { relevance }\end{array}$ & $\begin{array}{l}7,5 \\
-\end{array}$ & $\begin{array}{l}\text { The proposed indicator is very } \\
\text { relevant in the composition of a } \\
\text { global indicator related to risk area }\end{array}$ \\
\hline
\end{tabular}

Table 5. Weights used for prioritization of indicators.

\begin{tabular}{|l|l|l|}
\hline Criteria & Wheight & \multicolumn{1}{|c|}{ Justifications } \\
\hline $\begin{array}{l}\text { Hardly } \\
\text { relevant }\end{array}$ & 1,0 & $\begin{array}{l}\text { The indicator derives from } \\
\text { subjective assessments or } \\
\text { have an history of low } \\
\text { frequency of occurrence }\end{array}$ \\
\hline Relevant & 3,0 & $\begin{array}{l}\text { The indicator stems from } \\
\text { objective assessments with } \\
\text { lower severity }\end{array}$ \\
\hline $\begin{array}{l}\text { Very } \\
\text { relevant }\end{array}$ & 5.0 & $\begin{array}{l}\text { The indicator runs from } \\
\text { objective assessments with } \\
\text { high severity }\end{array}$ \\
\hline
\end{tabular}

For this purpose, it was established a prioritization matrix composed of columns and rows which was prepared for each subgroup related to both preventive and reactive focus. In columns were listed for each subgroup indicators, and for each one were assigned 
grades and weights. This methodology adaptation was already tested in the environmental area for the global suitability indicators and proved to be satisfactory [25].

This method allows separate evaluations on criteria that point the relevance of each indicator through grades and use this value associated to given weights (weighted by multiplying), we have direct relationship with its importance in a general scenario, i.e., the higher these factors, the greater relative importance of such a specific indicator [26].

\subsubsection{Normalization}

The normalization of the indicators used in each subgroup was conducted according to procedures established by the United Nations (UN) in the composition of the Human Development Index (HDI) for the data comparison between different countries. It consists in adjust data within interval $[0,1]$ and make it comparable to each other so that they can compose a global indicator, as showed in equation 1 [27] [28] [29].

$$
\bar{X}_{w}{ }^{i, j}=\frac{X_{w}{ }^{i, j}-\min \left(X_{w}{ }^{i, j}\right)}{\max \left(X_{w}{ }^{i, j}\right)-\min \left(X_{w}^{i, j}\right)}
$$

The meaning of variables is:

$i$ : platform

$j$ : company

$w$ : index of specific indicator:

$X_{w}{ }^{i, j}$ specific indicator $\mathrm{w}$

$\bar{X}_{w}{ }^{i, j}$ : normalized indicator derived from specific indicator $\mathrm{X}_{\mathrm{w}}$

$\min \left(X_{w}{ }^{i, j}\right):$ minimum value of the specific indicator w across all platforms

$\max \left(X_{w}{ }^{i, j}\right)$ : maximum value of the specific indicator $w$ across all platforms

\subsubsection{The global indicators}

The leading and lagging variables were incorporated, respectively, as Global Leading indicator (IGPRV) and Global Lagging Indicator (IGRTV) through a sum according to Equation 2.

$$
I G_{i, j}=\sum_{n=1}^{n} V^{X_{w}} * \bar{X}_{w}^{i, j}
$$

The meaning of variables is:

$I G$ : Global Indicator for the company's $J$ and platform $I$
$V^{X_{w}}$ :Coefficient contribution percentage assigned to specific indicator within the prioritization performed for the respective segment;

$\bar{X}_{w}{ }^{i, j}$ : Normalized indicator derived from specific indicator $X_{w}$

$n$ : number of specific indicators of the respective segment.

\section{Results and Discussion}

The table 6 and 7 shows a summary of prioritization results obtained in leading and lagging indicators, showing the relative importance of specific indicators using the methodology already presented.

The tables 6 and 7 show the relative importance of information raised by a specific indicator compared to others. Each one has a weight that put it in a position that will impact on the final result of the respective global indicator and its position was obtained based on opinion of specialists that are the most used method for this kind of hierarchy process [29].

To analyze the results, real data from 2011 was used in 67 offshore production platforms and after normalization of specific indicators using equation 1 , equation 2 was applied. The previous obtained values $\left(\bar{X}_{w}{ }^{i, j}\right)$ have been multiplied by respective weighting values ( $V^{X_{w}}$ ) to achieve both global indicators that add the contribution of each specific indicator to achieve one final number. The final results were divided into quartiles as shows figure 2 .

For IGPRV case, the greater value of the indicator, better is the platform safety practices compared to others. In a opposite way, as higher is the IGRTV, worse is the results of the risk management for the specifc platform.

As presented, the IGPRV and IGRTV are showed respectivily at upper and lower part of figure 2 and allow the behavior identification of implementation effort to follow SGSO requirements (IGPRV) and also give us information about the precursor events of major accidents (IGRTV), based on the lowest and highest values of specific good safety practices indicators.

As IGRTV exhibits low values for a considerable number of platforms, it can deliver a false output that might indicates that no further actions are needed. However, if this kind of data is used alone in a safety analysis, it may lead actions that are not enough to avoid major accidents. This results may indicate that the cut lines established in the lagging approach may need a 
further stratification to incorporate a greater number of related events or a more extended period of time [31]. In the other hand, it is not possible aim a good safety performance analysis looking just at leading indicators and forget the results showed by lagging indicators [6].

However, important management information can be raised from global indicators like showed in Fig. 2. For instance, if a non desirable performance is identified, the weakness in risk management can be analyzed as showed in Fig. 3.

Table 6. Prioritization Results of indicators in the leading focus.

\begin{tabular}{|c|c|c|}
\hline Indicator & Results & $\begin{array}{c}\text { Normalized value } \\
\left(V^{X_{w}}\right)(\%)\end{array}$ \\
\hline $\begin{array}{l}\text { Compliance with } \\
\text { recommendations of } \\
\text { risk assessments } \\
\end{array}$ & 367,0 & 6,35 \\
\hline $\begin{array}{l}\text { Risk assessment in } \\
\text { change management }\end{array}$ & 324,0 & 5,61 \\
\hline ESDVs Tests & 323,2 & 5,60 \\
\hline PSVs Tests & 323,2 & 5,60 \\
\hline BDVs Tests & 322,0 & 5,58 \\
\hline $\begin{array}{l}\text { Fire detections System } \\
\text { test }\end{array}$ & 317,3 & 5,49 \\
\hline $\begin{array}{l}\text { Gas detections } \\
\text { System Test }\end{array}$ & 317,0 & 5,49 \\
\hline $\begin{array}{l}\text { Risk Assessment in } \\
\text { the Work Permits }\end{array}$ & 284,5 & 4,93 \\
\hline Personal Qualification & 283,1 & 4,90 \\
\hline $\begin{array}{l}\text { Start up testing of fire } \\
\text { pumps }\end{array}$ & 280,6 & 4,86 \\
\hline Deluge System Test & 273,3 & 4,73 \\
\hline $\begin{array}{l}\text { Implementation of } \\
\text { audit corrective } \\
\text { actions }\end{array}$ & 263,1 & 4,56 \\
\hline $\begin{array}{l}\text { Implementation of } \\
\text { incident investigations } \\
\text { corrective actions }\end{array}$ & 258,5 & 4,48 \\
\hline $\begin{array}{l}\text { Awareness and } \\
\text { Participation }\end{array}$ & 248,8 & 4,31 \\
\hline $\begin{array}{l}\text { Risk analysis } \\
\text { recommendations } \\
\text { acceptance }\end{array}$ & 367,0 & 3,90 \\
\hline $\begin{array}{l}\text { Temporary } \\
\text { Management of } \\
\text { changes }\end{array}$ & 219,0 & 3,79 \\
\hline $\begin{array}{l}\text { Accidental Scenarios } \\
\text { drills }\end{array}$ & 215,0 & 3,72 \\
\hline
\end{tabular}

\begin{tabular}{l|c|c}
\hline Level of investigation & 214,0 & 3,71 \\
\hline Goal attainment & 212,7 & 3,68 \\
\hline $\begin{array}{l}\text { Deadline Attendance } \\
\text { for corrective actions } \\
\text { of audits }\end{array}$ & 180,6 & \\
\hline Evaluation level & 172,5 & 2,13 \\
\hline Work permits & 150,0 & 2,60 \\
\hline Total / normalized & 5775,4 & 100 \\
\hline
\end{tabular}

Table 7. Prioritization Results of indicators in the lagging focus.

\begin{tabular}{l|c|c}
\hline Indicator & Results & $\begin{array}{c}\text { Normalized } \\
\text { Value }\left(V^{X_{w}}\right) \\
(\%)\end{array}$ \\
\hline $\mathrm{H}_{2} \mathrm{~S}$ release & 420,5 & 10,32 \\
\hline $\begin{array}{l}\text { Major Natural Gas } \\
\text { Leaks }\end{array}$ & 419,0 & 10,29 \\
\hline Major fire & 419,0 & 10,29 \\
\hline Oil spills with fire & 406,0 & 9,97 \\
\hline Major spills & 405,0 & 9,94 \\
\hline Significant fire & 360,0 & 8,84 \\
\hline
\end{tabular}

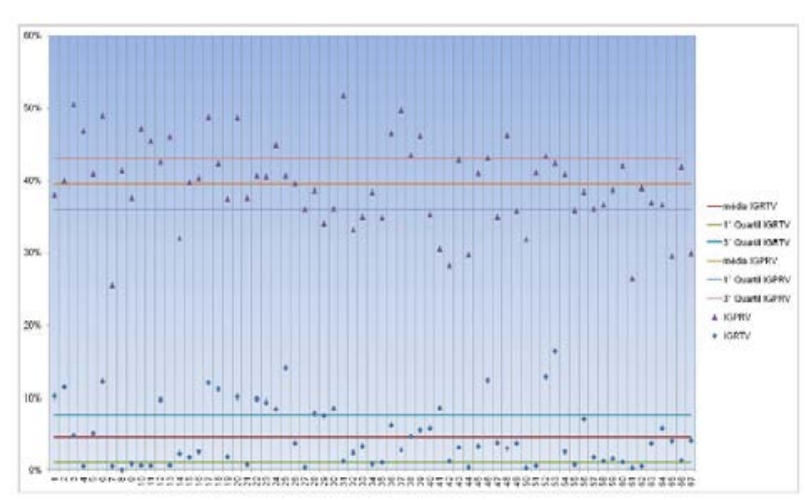

Fig. 2. Leading Global Indicator (IGPRV) and Lagging Global Indicator (IGRTV) to 67 production platforms.

\begin{tabular}{l|c|c}
\hline Major collision & 339,1 & 8,32 \\
\hline $\begin{array}{l}\text { Significant Natural Gas } \\
\text { Releases }\end{array}$ & 282,5 & 6,94 \\
\hline Significant spills & 278,0 & 6,82 \\
\hline Oil spills without fire & 264,8 & 6,50 \\
\hline Significant collision & 245,5 & 6,03 \\
\hline $\begin{array}{l}\text { Plant shutdowns in } \\
\text { emergency }\end{array}$ & 234,0 & 5,74 \\
\hline Total / normalized & 4073,4 & 100 \\
\hline
\end{tabular}



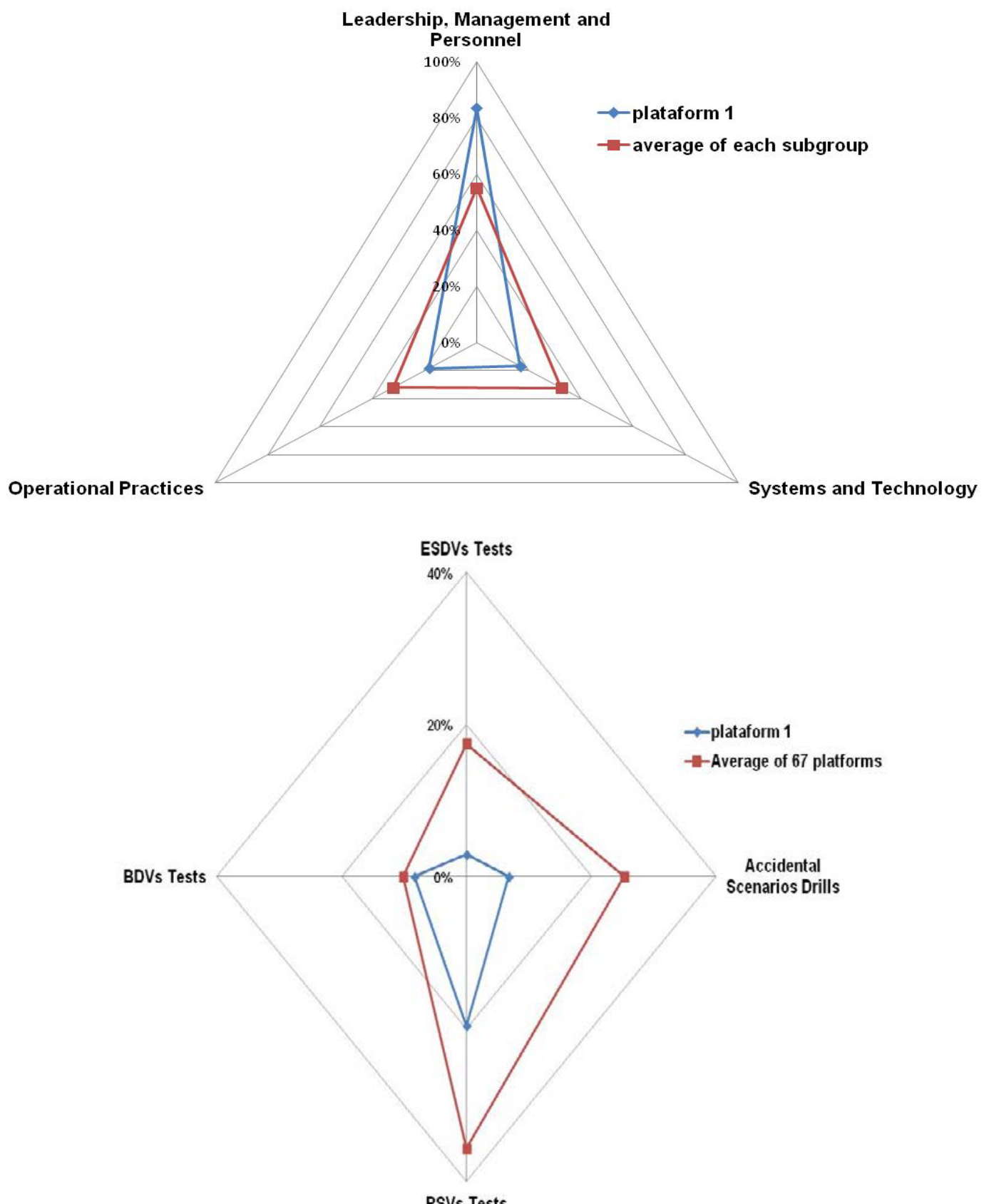

Fig. 3. Analyses of one specific result for IGPRV for a chosen platform.

Fig. 3 shows that once a bad result is identified for a specif platform, the global information can be analysed in a more deep perpective, looking for the causes of this output. On the left its shows the subgroups of IGPRV results compared to a general average. After find the lower performance subgroup, the specific indicators can be analysed as showed on the right side of figure 3 and specific actions can be adressed to improve these results. Furthermore, this kind of analyses can be expanded to an oil companies by adding the diferent results of their own platforms for a more amplied scope.

\section{Conclusions}

This study aimed to generally discuss the topic of process safety in offshore oil and gas production platforms in order to propose a model of global 
indicators to turn easier to regulators to identify weaknesses in a process safety management based regulation. It can be useful to point possible improvement opportunities, optimize regulators resources finding inspection opportunities and enforce an operational safety continuous improvement environment.

Thus, from a leading point of view, it was found that knowing the real position of companies in meeting the need of implementing a regulatory PSMS, identifying key practices for the adoption of such a system and, therefore, measuring the implementation ongoing efforts has direct impact in avoiding major accidents. In other hand, measuring the occurrence of minor damage precursors events (near misses) and accidents has to be the focus to a lagging monitoring.

The adequacy of the proposed indicators as instruments of information and evaluation came from numerous studies that incorporated different perceptions and different methods of analysis and safety monitoring, enabling the proposal of a mechanism for the safety assessment process [30].

In this context and within analyzed data, it was found that the proposed global indicators allow weaknesses identification at individual platforms level, which can be expanded to oil companies and platform operators, allowing regulatory and other management levels to act aiming to avoid undesirable behaviors and, in the end, avoid main situations that can lead a major accident.

In this aspect, the indicators used and normalization procedure allow different levels of comparisons analysis and lead to compare platforms inside an oil company, platforms from different companies and even companies. It turns easier the establishment of performance goals and proactive regulatory oversight of the industry.

It was found in the data analysis, confirming texts that performance monitoring programs based on purely leading or lagging data can lead weak or insufficient outputs, which do not allow a proper conclusion of the current status of safety of ongoing processes [6] [31]. On this way and to improve results analysis was found a need to improve lagging data analysis, maybe changing the data horizon, expanding the analysis period. Other study opportunity is try to find the best fit to correlate both leading and lagging global indicators.
As result of this research, considering the methodology procedure, it has allowed to measure the performance of global indicators in a given period of time, observing their variations in a large number of production platforms operating in Brazil. In this same perspective, it could be seen that the use of global indicators proposed can address the proposal needs. However, a demand of this kind of method is the adoption of continuous improvement safety culture for companies which data are required and for regulator's analysis mechanisms, in order to maintain the characteristics, sensitivity, robustness and simplicity in the conditions of measurement and analysis to reach desirable results [6] [29].

In this sense, it is expected that the evaluation of data from IGPRV and IGRTV may be added with additional information from other processes such as information audits conducted by the regulator and causes of incidents correlated to PSMS, among others, could significantly improve the regulatory management process. It can lead a designing of companies risk management profiles, or other results outside the scope of this text, but preliminarily discussed in the data analysis.

The presented indicators are designed to simplify analysis by quantifying subjective and complex concepts for establishing goals and to allow assess performance in regulated industry. As showed, it can be used to articulate concepts of process safety and regulatory action to allow identification and dissemination of best practices in risk management [5] [9] [10] [32]. This perception aims to improve resources destination in regulatory bodies improving actions to achieve the main focus of avoid major accidents.

\section{References}

[1] Harsem, Ø.; Eide, A.; Heen, K.; Factors influencing future oil and gas prospects in Artic, Energy Policy v.39, p. 8037-8045, 2011.

[2] US Energy Information Administration (EIA), Annual Energy Outlook - Reference Case, 2011.

[3] American Institute of Chemical Engineers (AIChE), Center for Chemical Process Safety (CCPS), Guidelines for Risk Based Process Safety, Wiley, 2007.

[4] Skogdalen, J.E.; Utne, I.B.; Vinnem, J.E. Developing safety indicators for preventing offshore oil and gas deepwater drilling blowouts, Safety Science, n. 49, p. 1187-1199, 2011. 
[5] United Kingdom Health and Safety Executive (HSE), Developing process safety indicators: a step-by-step guide for chemical and major hazard industries, 2006.

[6] Vinnem, J. E. Risk Indicators for major hazards on offshore installations. Safety Science. 2010.

[7] American Institute of Chemical Engineers (AIChE), Center for Chemical Process Safety (CCPS), Guidelines for Process Safety Metrics, Wiley, 2010.

[8] Deepwater Horizon Incident Joint Investigation (DHJIT). Marine Board of Investigation into Marine Casualty, Explosion, Fire, Pollution and Sinking of Mobile Offshore Drilling unit Deepwater Horizon, with the Loss of Life in the Gulf of Mexico, April 20-27, 2010. The US Coast Guard/Bureau of Ocean Energy Management, Regulation and Enforcement (BOEMRE) Joint Investigation Team, 2010.

[9] Petroleum Safety Authority Norway (PSA), Summary report 2010 - Norwegian Continental Shelf Trends in Risk Level in Petroleum Activity, 2011.

[10] United Kingdom Health and Safety Executive (HSE), Key Programme 3 Report, Asset Integrity Programme, HSE's Hazardous Installations Directorate. 2007.

[11] Bullen, P. Performance Indicators - New management jargon, political marketing, or one small element in developing quality services? Caring, the Association of Children's Welfare Agencies Newsletter (Editorial Comment), september edition, 1991.

[12] Kiyan, F.M.; Proposal for development of performance indicators to support strategic, Universidade de São Paulo, 2001.

[13] Øien, K.; Utne, I.B.; Herrera, I.A.; Building Safety indicators: Part 1 - Theoretical foundation, Safety Science, n. 49, p. 148-161, 2010.

[14] Hopkins, A., The Limits of Lost Injury Frequency Rates - Positive Performance Indicators for OHS Part 1. Proceedings. Canberra: Worksafe Australia, 1994.

[15] Lethinen, E.; Wahlstorom, B., Safety Performance Measurement in Process Industries, Third International Conference on Performance Measurement and Management, 2002.

[16] International Association of Oil and Gas producers (OGP), Process Safety - Recommended Practice on Key Performance Indicator, Report n. 456, 2011.

[17] Vinnem, J. E., Aven, T., Husebø et al., Major hazard indicators for monitoring of trends in the Norwegian offshore petroleum sector, Reliability Engineering \& System Safety,n. 91, p. 778-791, 2006.

[18] Seath, I.; Lead vs. Lag Indicators, Ian Seath's Blog, http://ianjseath.wordpress.com/2009/08/26/lead-vs-lagindicators/, 2009, (accessed Jan. 6, 2013).

[19] Levy, J.de Q. Beaumont, J. Indicador Global de Ruído http://www.ecoservicos.pt/page.jsp?section $=$ cientificos\&page=pubs (Accessed Dez. 02, 2009)

[20] Brazilian National Agency of oil, Natural Gas and Biofuels (ANP), ANP Resolution 43/2007, 2007.

[21] Almeida, A. C. C.; Bardy, M. B.; Risk Assessment to the business due to accidents in process plants, Det Norske Veritas (DNV), 2006.

[22] Giannetti, E.; Almeida, C. Industrial Ecology Concepts, Tools and Applications. São Paulo: Ed. Edgard Blücher, 2006 apud SÂO JOSÉ, Andreia Silva; Identification of global indicators for Social Responsability and Sustainabilityl, 2010. 125 f.,Universidade do Estado do Rio de Janeiro, 2010.

[23] Kraemer, M. E. P. Tinoco, J. E. P. Contabilidade e gestão ambiental. São Paulo: Ed. Atlas, 2004.

[24] Freeman, H.M., Hazardous waste minimization, McGraw-Hill Publishing Company. New York, USA 1990

[25] SÂO JOSÉ, Andreia Silva; Identification of global indicators for Social Responsability and Sustainabilityl, 2010. 125 f.,Universidade do Estado do Rio de Janeiro, 2010.

[26] Matarazzo, Dante C. Análise Financeira de Balanços: Abordagem básica e gerencial. 5a Ed. São Paulo: Atlas, 1995 apud SÂO JOSÉ, Andreia Silva; Identification of global indicators for Social Responsability and Sustainabilityl, 2010. 125 f.,Universidade do Estado do Rio de Janeiro, 2010.

[27] United Nations (UN), Human Devellopment Report 2011, 2011.

[28] Organization for Economic Co-operation and Development (OECD), Handbook on Constructing Composite Indicators - Methodology and user guide, 2008.

[29] Organization for Economic Co-operation and Development (OECD), Handbook on Constructing Composite Indicators - Methodology and user guide, 2008 apud CARVALHO, J.A.B.; Uma proposta de agupamento de indicadores para a avaliação da efetividade da segurança de usinas nucleares, Dissertação de Mestrado, UFRJ - COPPE, 2009.

[30] Almeida, A.G.; Henrique , N. I.; Lemos, T.S.M.; Analysis from released data by offshore safety regulators: typical profiles and parameters for the establishment of a Brazilian methodology, Rio Oil and 
Gas Conference and Expo, 2012.

[31] International Association of oil and gas producers (OGP), 2011.Process Safety - Recommended Practice on Key Performance Indicator, 2011.

[32] United Kingdom Health and Safety Executive (HSE), A Guide to Health \& Safety Performance measuring, 2001. 